\title{
Strength analysis and modal analysis for the load-bearing structure of the equipment for opening and compartmentalizing watering furrows, using 1D
}

\author{
Petru Cardei ${ }^{1,{ }^{*}, \text { Raluca Sfiru }}{ }^{1}$, Marius Oprescu ${ }^{2}$, Vergil Muraru ${ }^{1}$, and Cornelia Muraru ${ }^{1}$ \\ ${ }^{1}$ INMA Bucharest, RDI, Bv. Ion Ionescu de la Brad no 6, Romania \\ ${ }^{2}$ INMA Bucharest, DITRMA-RENAR, Bv. Ion Ionescu de la Brad no 6, Romania
}

\begin{abstract}
The paper proposes the analysis of the load-bearing structure of the equipment for opening and compartmentalizing watering furrows (EOCFW), using a 3D structural model, built with 1D finite element. Based on information from the experimental results of the EOCFW equipment, the load-bearing structure is supported and loaded. The results of the linear static analysis of the structure consist of the distributions of the relative displacement fields and the equivalent voltage in the structure. Also, the own frequencies of the structure and the deformed forms of the structure are obtained when it vibrates in its own ways with the lowest own frequencies. It shows how these results can be used. The field of relative displacements is used to assess the effects on the quality of the soil processing performed. The equivalent stress field is used to estimate the safety factor of the structure, by reference to the flow stress of the material from which the structure is built. The first four or five own frequencies are important for the prognosis of possible vibration regimes with resonance, their explanation and their amelioration. It emphasizes the ease with which the model can be modified to obtain improved or even optimized variants.
\end{abstract}

\section{Introduction}

Structural analysis is a modern tool, but already normal in the research of physical phenomena and the design of industrial, civil or other products. The tool is modern today because it constantly addresses new topics and deepens the already classic ones.

In the field of agricultural machinery, structural analysis has gained intense use in the last fifty years. In addition to the hesitant beginnings, in the last twenty years, there have been many works related to the design of equipment used in agriculture or the structural modelling of physical processes in agriculture, [1]. A review of the use of MEF in the field of agricultural mechanization is, for example $[2,5]$. Most of the literature of the last 20 years, in this field, proposes models with solid (three-dimensional) finite elements, $[3,4,6$, 7-13].

\footnotetext{
* Corresponding author: petru cardei@yahoo.com
} 
3D structural models, built with 1D bar-type finite elements, are older than those built with 3D finite elements. Mathematical models of the straight bar (Euler or Tymoshenko, for example) were used long before the appearance of the finite element method. The finite element method integrated these mathematical models. 3D structural models built with 1D finite elements are also well known in the literature in the field of agricultural machinery, [1, 14-17]. Structural models built with 1D finite elements are well suited to large structures formed with relatively thin bars, such as the load-bearing structures of bridges, vehicles or agricultural machinery [18-20]. The literature still abounds with examples of the use of 3D structural models, mashed with 1D or mixed finite elements, hybrid models that contain 1D elements (of the bar or beam type). This category also includes the model presented in this paper. The advantages and disadvantages of this model are presented in relation to the $3 \mathrm{D}$ models mashed with 3D elements. On the other hand, the usefulness of such a model in the research - design activity for certain structures, signalled above, is also argued, their structural models simplifying the calculation procedures and the interpretation of the results. Research on the testing of agricultural equipment in real field conditions was carried out by [27, 29, 33], simulation by finite element analysis (FEM) [24, 28, 31, 32], on special installations/test stands in regime simulated and accelerated $[26,30,31]$ or theoretical research [25], to identify and develop the most modern constructive solutions [34], similar to those carried out worldwide.

\section{Material and method}

The subject of the analysis, the results of which are presented in the article, is the loadbearing structure of EOCFW, fig. 1 .

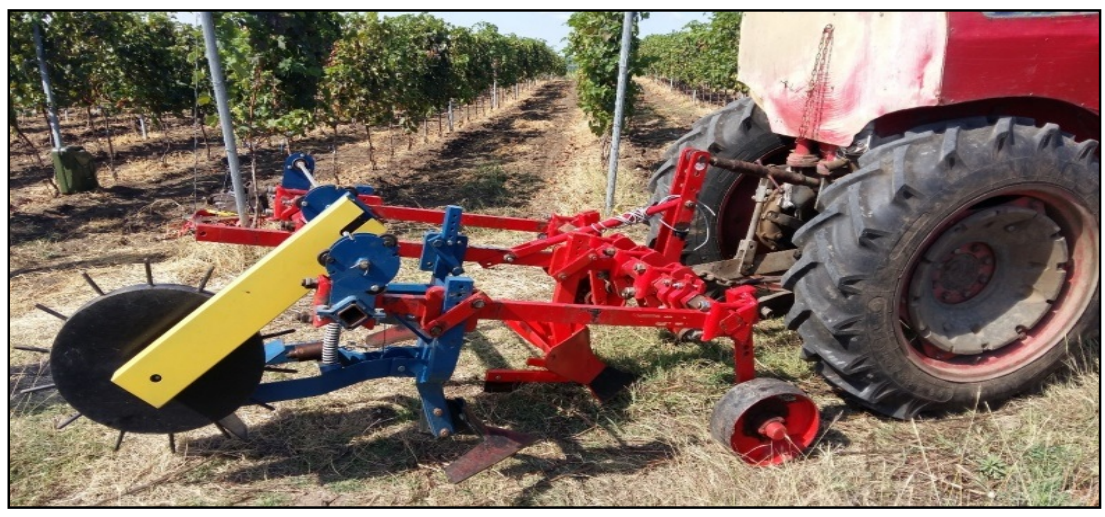

Fig. 1. Rotor version of the load-bearing structure of the EOCFW.

The structural model (geometry, fixing conditions and loads, elements and nodes) of the load-bearing structure of EOCFW, is presented in fig. 2. There is a difference between the load-bearing structure of the EOCFW and the entire structure of this machine. The working organs (the double mouldboard and the palette) are represented in the model only by the forces with which they act on the load-bearing structure. Fixing the structure or the conditions on the border means cancelling the relative linear displacements in the articulation points to the tractor. The loading is done with the force of $4500 \mathrm{~N}$ from the double mouldboard side and $700 \mathrm{~N}$ from the blade side, in the direction of movement in the opposite direction to the direction of movement of the unit. A force of $100 \mathrm{~N}$ acts on the resistance frame (the load-bearing structure) in the same direction and in the same sense as the other two forces, as a result of the resistance of the copy wheel, fig.2. The material of 
the structure, for linear static analysis and modal analysis, is characterized by the linear elasticity modulus, $E=2.0 \cdot 10^{11} \mathrm{~Pa}$, the Poisson's ratio $v=0.29$ and the density $\rho=7900 \mathrm{~kg}$ $/ \mathrm{m}^{3}$. The model is mashed with ninety-eight nodes and ninety BEAM3D elements included in the finite element library of the COSMOS / M 1.75 program, [21].

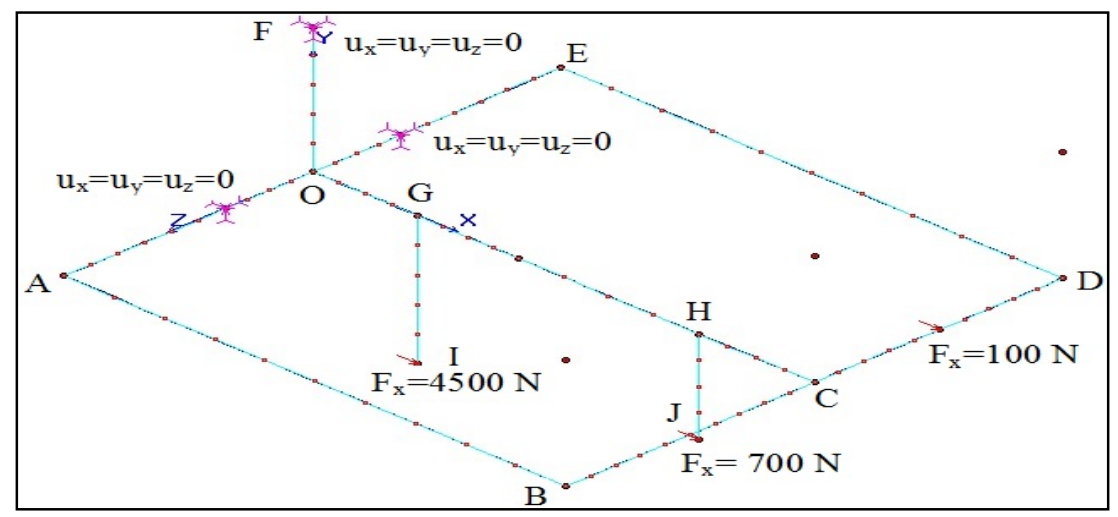

Fig. 2. Rotor or cam version of the load-bearing structure of the EOCFW.

The characteristics of the cross-sections of the bars used in the construction of the structural model of the load-bearing structure of the EOCFW are given in Table 1.

Table 1. Characteristics of cross-sections of EOCFW structural model profiles.

\begin{tabular}{|c|c|c|c|c|c|}
\hline Beam, section, $\mathbf{m m}$ & $\begin{array}{c}\text { Area, } \\
\mathbf{m m}^{\mathbf{2}}\end{array}$ & $\begin{array}{c}\text { Moment of } \\
\text { inertia, } \\
\mathbf{I x , \mathbf { m m } ^ { 4 }}\end{array}$ & $\begin{array}{c}\text { Moment of } \\
\text { inertia, Iy, } \\
\mathbf{m m}^{\mathbf{4}}\end{array}$ & $\begin{array}{c}\text { Depth, } \\
\mathbf{m m}\end{array}$ & $\begin{array}{c}\text { Width, } \\
\mathbf{m m}\end{array}$ \\
\hline $\begin{array}{c}\text { AO,OE, BC, CD, } \\
\text { Caisson, 60x60x6 }\end{array}$ & 1296.0 & 63.76 & 63.76 & $\begin{array}{c}84.852 \\
(60)\end{array}$ & $\begin{array}{c}84.852 \\
(60)\end{array}$ \\
\hline $\begin{array}{c}\text { AB, OC, ED, GI, HJ } \\
\text { 55x30 }\end{array}$ & 1650 & 12.375 & 41.594 & 55.0 & 30.0 \\
\hline OF & 1440 & 1.728 & 43.2 & 60 & 84 \\
\hline
\end{tabular}

\section{Results}

The main results of the two analyzes are relative displacement field (values in nodes), the tensor field of Cauchy stresses (average values per element), reaction values, deformed shape of the structure (from static linear elastic analysis), respectively: the lower first five eigenfrequencies and the deformed shapes of the structure when it vibrates in the corresponding eigenmodes.

\subsection{The main results of the linear elastic analysis}

The vector field of relative displacement or the deformation field as it is called in engineering language has three components, corresponding to the three axes of the absolute reference system. Therefore there are three scalar fields of relative displacements in the directions of the three coordinate axes. A scalar field of the relative deformation, which reflects the overall displacement, is that of the resultant relative displacement, whose distribution in the structural model is given in fig. 3 . 
The stress field has in this model two main components, the axial stress field and the equivalent stress field (Von Mises), [21]. In fig. 4 represents the map of the average equivalent stress field distribution for each element of the model.

The maximum value of the relative displacement is $4.96 \mathrm{~mm}$ and corresponds to the component along the vertical axis at the ground plane (Oy). The maximum value of the equivalent stress in the structure is $123 \mathrm{MPa}$, is located at the upper part of the double mouldboard support and at the lower part of the beam with which the structure is coupled to the upper link of the tractor.

Reaction values at the tractor points of linked to the load-bearing structure is given in Table 2 .

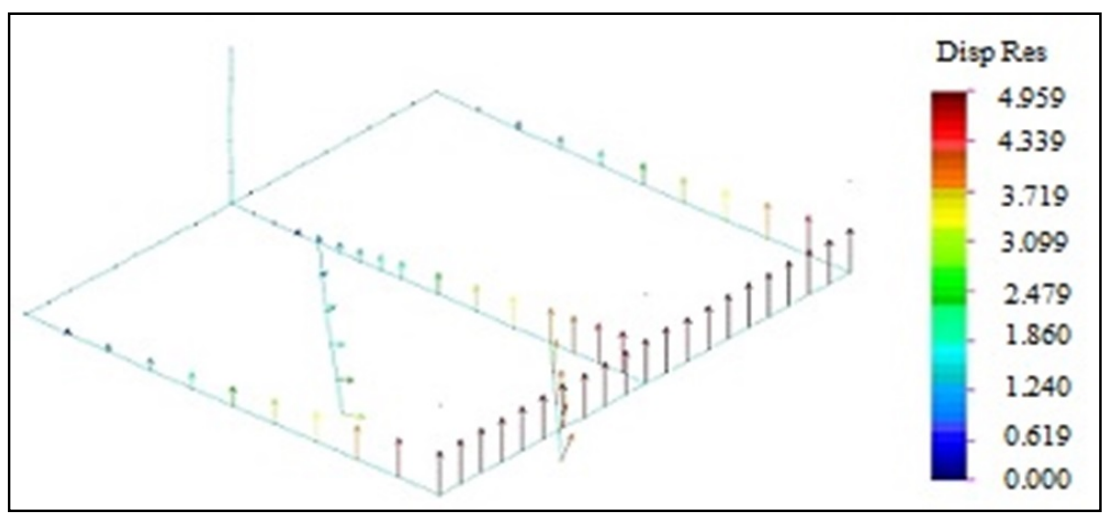

Fig. 3. Distribution of the resultant relative displacement field in the load-bearing structure of the EOCFW, in mm.

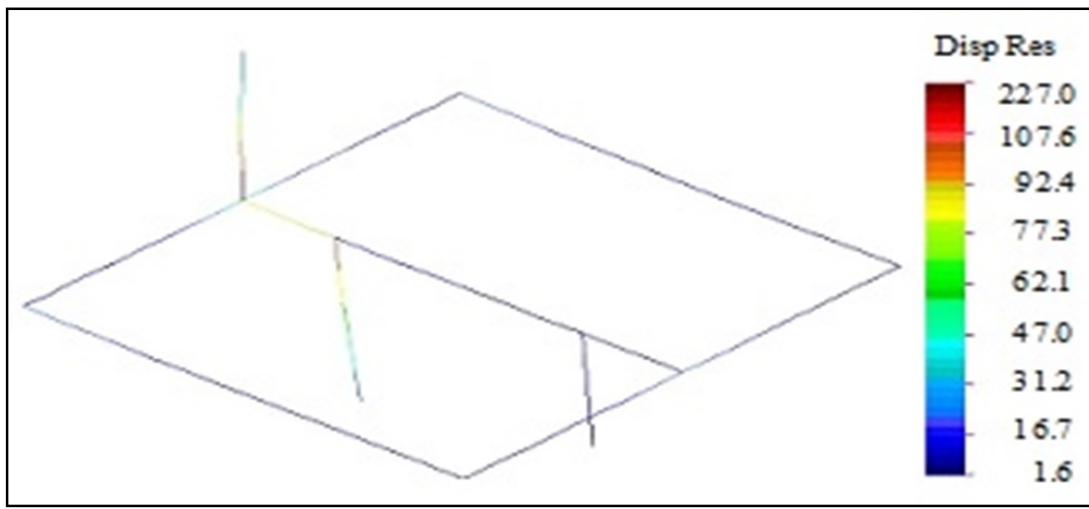

Fig. 4. Distribution of the Von Mises stress field in the load-bearing structure of the EOCFW, in MPa.

Table 2. Reaction values at tractor points for load-bearing structure an EOCFW.

\begin{tabular}{|c|c|c|c|c|}
\hline Place & Ox reaction, $\mathbf{N}$ & Oy reaction, $\mathbf{N}$ & Oz reaction, $\mathbf{N}$ & Resultant, $\mathbf{~}$ \\
\hline Right link & -5115.0 & -843.1 & 5.7 & 5184 \\
\hline Central link & 5072.0 & 168.6 & 0.0 & 5345 \\
\hline
\end{tabular}




\begin{tabular}{|c|c|c|c|c|}
\hline Left link & -5258.0 & -843.1 & -5.7 & 5325 \\
\hline Total & -5300.0 & 0.0 & 0.0 & 5300 \\
\hline
\end{tabular}

\subsection{The main results of the modal analysis}

The first five eigenfrequencies of the structure, in $\mathrm{Hz}$, have, in ascending order, the values: $17.57,24.60,42.44,107.48$, and 126.62. The deformed shapes of the structure when it vibrates on one of its own frequencies, help to determine the components of the assembly, which most likely causes a possible movement with high amplitude or even resonance.

\section{Discussion}

In addition to the results presented in the previous chapter, the FEA program that solves the analysis of the structural model, COSMOS / M 1.75, [21], also provides other results. These results include the inertial characteristics of the entire structure, for example, the mass of $70.07 \mathrm{~kg}$, the length, the area and the volume of the model bars, the geometric and mass moments of inertia usable in calculations of the aggregate dynamics, the coordinates of the mass centre and radius of gyration. The mass given by the program is smaller than the mass of the EOCFW because it does not include the working organs and the additional elements for their support or guidance (in total, around $110 \mathrm{~kg}$ ). The presented model is the simplest possible with natural loads in forces derived from experimental data, [22]. Obviously, the model can be complicated by the introduction of working organs and additional guiding elements.

For ordinary steels, the yield strength (at the end of which irreversible deformations begin to occur), has the value of about $220-230 \mathrm{MPa}$. Taking into account the maximum value of the equivalent stress in the structure (fig. 4), a safety factor of 1.8, [23], that required in the standards for agricultural machinery and equipment, results. If the structure is built with steel whose minimum yield stress value is $351,571 \mathrm{MPa}$, then the minimum safety factor of the structure is 2.86 .

\section{Conclusion}

The results presented in the paper show that a mashed 3D structural model with 1D finite elements (Tymoshenko bars), is particularly useful in the rapid design of a load-bearing structure if sufficiently precise loading assumptions and boundary conditions are known. Changing the bars of the structure is very simple because the design does not change but only the numerical characteristics of their cross sections change. The changes, purely numerical, are made simply in the database. In this way, the bars are replaced by probing until a safety factor is reached in accordance with the standards and a negligible deformation for the working process. In the same way, some vibrations that can affect the work process can be largely removed. This optimization process can be also operated on the experimental model after detecting some deficiencies in the tests carried out in the field.

The use of mashed 3D structural models with 1D type elements is useful at a first start design, it is simple and fast compared to the direct calculation on mashed structural models with 3D finite elements (SOLID). 3D CAD-CAM models are models prepared especially for execution documentation. Their use in the structural analysis must go through the stage of transformation into a CAD - CAE model (elimination of gaps and interferences, 
mashing). Modifications by probing beams or other components are difficult, often involving redesign. For this reason, a mashed 3D structural model with 1D elements (possibly also 2D) is useful, the pre-design made with its help greatly limiting the calculation on models with 3D finite elements or even eliminating it.

\section{Acknowledgement}

This work was supported by a grant of the Ministry of Research, Innovation and Digitization (MRID), CCCDI - UEFISCDI, project number PN-III-P1-1.2-PCCDI-2017-0560 "Eco-nanotechnologies and intelligent equipment for soil properties mapping and evaluating the dynamics of the plant in order to improve agricultural production and environmental protection, within PNCDI III and was done by "NUCLEU” Programme, developed with the support of MRID project PN 19100102.

\section{References}

1. P. Cardei, and others, Structural analysis and new materials focused on mechanics, mechatronics, maintenance and operation of technical equipment for agriculture and food industry, Terra Nova Publishing Iasi, (2012)

2. N. S. Velloso, A. L. Costa, R. R. Magalhães, F. L. Santos, E. T. D. Andrade, The Finite Element Method Applied to Agricultural Engineering: A review, Current Agriculture Research Journal, 6(3), 286-299, (2018)

3. H. K. Celik, R. Cinar, G. Kunt, A. E. W. Rennie, M. Ucar, I. Akinci, Finite Element Analysis of a PTO Shaft Used in an Agricultural Tractor, Ergonomics International Journal, 2(3), (2018)

4. M. Boryga, P. Kolodziej, Stress analysis of the sugar beet lifter with the finite element method (FEM), Agricultural Engineering, 23(3), 29-39,(2019)

5. Y. Shen, Soil-Machine Interactions A Finite Element Perspective, CRC Press, (1998)

6. P. Bazyar, A. Jafari, R. Alimardani, V. Mohammadi, J. Grichar, Finite Elements Analysis of Small-scale Head of Combine Harvester for Harvesting Fine-Grain Products, International Journal of Advanced Biological and Biomedical Research, 8(4), 339-357, (2020)

7. N. Nankali, M. Namjoo, M. R. Maleki, Stress Analysis of Tractor Tire Interacting with Soil using 2D Finite Element Method, International Journal Advanced Design and Manufacturing Technology, 5(3), 107-111, (2012)

8. F. Tian, Y. Chen, Z. Song, Y. Yan, L. Fade, Z. Wang, B. Xiong, Finite Element Simulation and Perforance Test of Loading and Mixing Characteristics of SelfPropelled Total Mixed Rotation Mixer, Journal of Engineering, 15 pag., (2020)

9. E. P. da Silva, F. M. da Silva, R.R. Magalhães, Application of Finite Elements Method for Structural Analysis in a Coffee Harvester, Engineering, 6, 138-147, (2014)

10. V. Vladut, E. Maican, L. Apostol, N. Ungureanu, I. Dumitru, R. Oprescu, Verification of Stress by FEM Analysis Mechanical Testing of Agricultural Mobile Aggregates Coupling Devices, INMATEH Agricultural Engineering, 54(1),39-46, (2018)

11. S. Șt. Biriş, Ungureanu N., Cujbescu D., Modelling of soil compaction under heavyduty tractors, INMATEH Agricultural Engineering, 57(1), 261-270, (2019)

12. G.A. Constantin, Gh. Voicu, B. Olac, F. Ilie, G. Paraschiv, V. Ştefan, G. Musuroi, Structural analysis with finite elements of a subsoiler working part, INMATEH Agricultural Engineering, 61(2), 61-26, (2020) 
13. G. Ipate, G. A. Constantin, S. Șt. Biriș, Gh. Voicu, C. O. Rusănescu, V. Ștefan, Numerical 3D analysis a mini wind turbine with horizontal axis, for implementation in agricultural farms, INMATEH Agricultural Engineering, 61(3), 325-333, (2020)

14. V. Nițescu, P. Cardei, V. Muraru, I. Cojocaru, R. Sfîru, Modalităţi de dimensionare a cilindrului hidraulic pentru mecanismul de reversare al unui plug reversibil, folosind cinematica și dinamica procesului de reversare, INMATEH Agricultural Engineering, 16(1), 163-168, (2006)

15. V. Muraru, N. Constantin, P. Cardei, R. Sfîru, Structural Analysis of MATINA soil working machine, INMATEH Agricultural Engineering, 31(2), 17-26, (2010)

16. I. Cojocaru, P. Cardei, M. Neacșu, Utilisation of elasto-plastic models of the soil in order to optimise the resistance structures of the chisel ploughs and to estimate their effects in soil, Proceedings of the International Conference "Soil Compaction and Crop Production, Gödölo, Hungary, (1998)

17. X. Wang, B. Li, Z. Yang, Finite Element Analysis and Lightweight Optimization Design on Main Frame Structure of Large Elecrostatic Precipitator, Advances in Materials science and Engineering, (2018)

18. M. H. Mat, A. R.Ab. Ghani, Design and Analysis of 'Eco' Car Chassis, Procedia Engineering 41, International Symposium on Robotics and Intelligent Sensors, 17561760, (2012)

19. S. Babak, A structural investigation to develop guidlines for the finite element analysis of the Mini-Baja vehicle, Electronic Theses and Dissertations, (2012)

20. I. Vayas, T. Adamakos, A. Iliopoulos, Three dimensional modeling for steel-concrete composite bridges using system of bar elements - modeling of skewed bridges, International Journal of Steel Structures, 11(2), 157-169, (2011)

21. Structural Researches and Analysis Corporation (SRAC), COSMOS/M Finite Element Analysis System, Version 1.75. Manuals: User Guide, Basic FEA System, Advanced Modules, Cammand Reference, (1995)

22. M.R. Oprescu, I. Gageanu, M. Cristea, Determining the qualitative working indices for various forms of the active body of a rut soil compartmentation equipment, E3S Web of Conferences 180, $03011(2020)$

23. I. I. Ștefănescu, C. Spânu, Organe de mașini, vol. I, Editura Europlus, Galați, (2009)

24. S.Şt. Biriş, V. Vlăduţ, N. Faur, A. Cernescu, O. Kabaş, M. Matache, I. Voicea, S. Bungescu, C. Popescu, FEM analysis / testing resistance of a tractor seat, Proceedings of the 43 International Symposium On Agricultural Engineering "Actual Tasks on Agricultural Engineering", Opatija, 189-200, (2015)

25. S.Şt. Biriş, N. Ungureanu, N.E. Gheorghiță, E. Maican, V. Vlăduţ, Theoretical research on enhancing the performance of cultivators working bodies, Proceedings of the 45 International Symposium On Agricultural Engineering "Actual Tasks on Agricultural Engineering", Opatija, 121-130, (2017)

26. D. Cujbescu, S.Șt. Biriș, Gh. Voicu, M. Matache, G. Paraschiv, V.Vlăduţ, M. Bularda, N. Ungureanu, Determination of sowing precision in simulated laboratory conditions, INMATEH - Agricultural Engineering, 61(2), 209-216, (2020)

27. D. Cujbescu, N. Ungureanu, V. Vlăduţ, C. Persu, R. Oprescu, E. Gheorghiţă, Field testing of compaction characteristics for farm tractor universal 445, INMATEH Agricultural Engineering, 59(3), 245-252, (2019)

28. D.I. Vlăduţ, S. Biriş, V. Vlăduţ, D. Cujbescu, N. Ungureanu, I. Găgeanu, Verification of stress by FEM analysis / mechanical testing of agricultural mobile aggregates couplig device, INMATEH - Agricultural Engineering, 54(1), 37-462, (2018) 
29. D.I. Vlăduț, V. Vlăduţ, I. Grigore, S. Biriş, Experimental research on qualitative indices of work for equipment for seedbed preparation in conservative system, 16th International Scientific Conference "ENGINEERING FOR RURAL DEVELOPMENT", 1174-1179, Jelgava, Latvia, (2017)

30. V. Vlăduţ, V. Gângu, I. Pirnă, S. Băjenaru, S. Biriş, S. Bungescu, Complex tests of the resistance structures in simulated and accelerated regime on hydropulse installation, Proceedings of the 35 International Symposium On Agricultural Engineering "Actual Tasks on Agricultural Engineering", 393-404, Opatija - Croaţia, (2007)

31. V. Vlăduţ, Matache M., Faur N., Biriş S., Paraschiv G., Bungescu S., Traction bar testing of a $161 \mathrm{~kW}$ tractor in simulated and accelerated regime and its analysis by finite elements method for determining its rupture resistance, Proceedings of the 37 International Symposium On Agricultural Engineering "Actual Tasks on Agricultural Engineering", 77-84, Opatija - Croaţia, (2009)

32. V. Vlăduţ, S. Biriş, S. Bungescu, N. Faur, A. Cernescu, M. Matache, O. Kabaş, G. Paraschiv, At. Atanasov, Gh. Ivan, The verification of stress by MEF analysis/ mechanical testing of a traction bar, Proceedings of the 43 International Symposium On Agricultural Engineering "Actual Tasks on Agricultural Engineering", 141-152, Opatija - Croaţia, (2015)

33. V. Vlăduţ, E. Marin, I. Grigore, S.Șt. Biriş, N. Ungureanu, G. Gheorghe, M. Matache, C. Persu, I. Voicea, D. Cujbescu, S. Bungescu, I. Kiss, C. Vlad, Field and laboratory wear testing of integral seedbed implement's chisel tines point, Proceedings of the 45 International Symposium On Agricultural Engineering "Actual Tasks on Agricultural Engineering", 131-140, Opatija - Croaţia, (2017)

34. L. Vlăduţoiu, P. Cârdei, V. Vlăduţ, L. Fechete - Modern trends in designing and selecting the machine / equipment for soil deep tillage, 16th International Scientific Conference "ENGINEERING FOR RURAL DEVELOPMENT", 1415-1420, Jelgava, Latvia, (2017). 